Marcin Jarzabek

\title{
THE VICTORS OF A WAR THAT WAS NOT THEIRS: FIRST-WORLD-WAR-VETERANS IN THE SECOND REPUBLIC OF POLAND AND THEIR EUROPEAN PEERS
}

\begin{abstract}
This article's aim is an analysis of the status of Polish veterans of the Great War in interwar period. Their position is discussed in a European context. The author underlines dichotomy between ex-servicemen from former Austro-Hungarian, German or Russian armies (constituting vast majority of the veterans in the Second Republic of Poland) and the 'independence fighters' (i.e. soldiers from the voluntary Polish formations like Legiony Polskie) in terms of their legal status and symbolic position. State privileged the group of former Piłsudski's Legionnaires and other 'independence fighters'. At the same time the majority of 'ordinary' veterans was offered little more than 'compassion'. Unlike in Germany or France, First World War veterans did not form any important mass movement. The dominant position of the relatively small group of 'Polish soldiers' over masses of 'soldiers-Poles', similar to the position of former Czechoslovak legionaries, can be therefore treated as specific to the new states of East Central and Southeast Europe.
\end{abstract}

Keywords: war veterans, First World War, II Republic of Poland, Polish Legions, Czechoslovak Legions

\section{I \\ INTRODUCTION}

Sixty-five million males from Europe, the Americas, Australia, Africa, as well as Turkey, India, and Japan, were drafted between 1914 and $1918^{1}$ : roughly, the population of the entire Germany, from Metz up to Memel, at the moment the Great War broke out. Of those, ten

${ }^{1}$ Paul Kennedy, The Rise and Fall of the Great Powers: Economic Change and Military Conflict from 1500 to 2000 (New York, 1988²), 272, as quoted in Ian F. Beckett, The Great War, 1914-1918 (Harlow, 2007²), 282. 
million were killed in warfare; others would die afterwards, adding to the death toll because of their inflicted wounds and contracted diseases. Once the fighting was over, those who survived could sooner or later finally return home and resume their everyday routines. But, could they, really? The latter occurred much more complex than it might have seemed. Upon those who formerly were the poilus, Tommies, or Kaczmareks (so were called in the German army the soldiers from Polish-speaking provinces), not only their individual problems, and the consequences of war wounds and traumas fell, but also the effects of post-war economic and social crises: the unemployment and impoverishment. Their war experiences and their usually tough return to the civilian life became the foundation upon which numerous associations of former soldiers were set up. Their numerical strength, purposes, interests, power and significance varied by country and its political realities; still, in terms of the European scale, mass associations of veterans formed a distinguishing mark of the interwar years.

The perspective of the countries and (their) veterans - or, as those concerned saw it, of the veterans and (their respective) countries - is therefore, potentially, one important perception of the period 1918-39. The latter, 'reverse', sequence is quite telling, since the former combatants treated their participation in the First World War warfare in terms of a generational experience, the one that rendered their own generation distinct from the others; thence, they considered it the sufficient grounds for them to exercise authority and enjoy respect. Roman Starzyński², former Polish Legionnaire and Director of the Polish Radio, affiliated with the Sanacja camp, expressed this view in a rather explicit manner in 1937, eighteen months before another World War broke out:

Our generation would never complain of boredom. We have been through a great war, joined a series of revolutions and upheavals, survived political and economic crises; there is a lot that we have seen, and learned, indeed. We have been named in Europe the 'Ex-Combatant' generation, and considered, owing to the merits we have gained for our countries, as holding the right to make decisions with respect to them. No wonder, this

${ }^{2}$ Roman was a brother of Stefan Starzyński, Lord Mayor of Warsaw and the Civil Commissioner of the city during the September 1939 Nazi attack on Warsaw. 
generation now wields power in Italy, as well as in Poland, or Germany; it claims authority in France ... ${ }^{3}$

Quite interestingly for us, Starzyński, once a soldier with First Brigade of the Polish Legions, referred to a common generational experience which, in his perception, was shared by most of the Europeans who before then fought in the war, himself included. It might have seemed that the Polish experience, along with those of the other countries that rose in 1918 from the ruins of the old world - such as Czechoslovakia and the Baltic countries - would have turned completely different, unfitting the situation of the western or southern Europe. None of those countries was a party to the war, all ended up as its beneficiaries, in one way of another. So, has there been a common experience of the 'war veteran generation' extending to all Europeans, or rather, there was a dominant narration told from the Western perspective versus the dispersed experiences of the Eastern Europe which pursued its own, 'peculiar paths'? Can one refer (and, if yes, on what a level) to the histories of former Polish Great-War soldiers as ones that have taken a different course than those of the other European soldiers? I will take Czechoslovakia as a point of reference - the country whose case was similar to Poland's but different from it in terms of the political context: more authoritarian in Poland, whilst more democratic in Czechoslovakia.

II

A 'NEW EUROPE' AND HER VETERANS: THE DISPARATE PATHS

War, especially a total war - and such was the 1914-18 conflict - is a democratic occurrence, in the most rudimentary meaning: it namely affects everybody, and especially, every fighting soldier, regardless of where he comes from, or what his background is. In parallel, the scale of (potential) experience of the affected individuals appears extremely wide and diverse. Individuals experiences of the soldiers within an army and even within a formation may prove extremely different from one another. All the same, when it comes to the shaping of

3 Roman Starzyński, Cztery lata $w$ stużbie Komendanta. Przeżycia wojenne 1914-1918 (Warsaw, 2012 [1937]), 27. 
group or collective projections or concepts, a uniform vision of the past tends to emerge. And it was no different with the First World War: the warfare was carried out on three continents, but it was the image of the Western Front, a several-hundred-kilometre-long section in Belgium and in the north of France, that has dominated the wartime narratives in historiography, in fiction works, motion pictures, museology, and the like. The idea of trench (or positional) warfare, the model examples being Ypres or Verdun, proved to be so pervasive that even those of the military who spent the entire time in the east of Europe, where the war seems to have been somewhat different, began sharing it when the war was still on. Eugeniusz de Henning-Michaelis, a Polish general in the Russian service, thus described the 'contemporary war' (which was still on then, in 1917) to the Polish leader:

the tremendous armies are lying buried [i.e. entrenched] one opposite the other, inert, apparently; months and months are passing without a battle, labours taut and tense are buzzing in the rear. ... [The soldiers] in the trenches are living, fighting, and dying; but any symptoms of life are only existing beneath the earth's level; anything that attempts to be living above it, is eradicated unwaveringly. ${ }^{4}$

Henning-Michaelis never joined the Western Front, and knew its conditions from press or literary accounts. And yet, his image of the war is closer to that portrayed by the novelists Ernst Jünger or Robert Graves than to what his soldiers encountered, for instance, during the Brusilov Offensive in 1916. Although trenches, machine guns, gas, artillery preparation, etc. were all known, clearly enough, to the Eastern Front, the warfare there was incomparably more focused on manoeuvring: the fronts were longer and more mobile, less entrenched and, to a considerable extent, dependent upon the rear-to-front supply system.

Our idea of the Great War is still, prevalently, very close to General Henning-Michaelis's portrayal. Neither Poland nor a few other East European countries have developed their own wartime experiences narrative(s) that would now be part of the European cultural canon. Probably the only exception to the rule is the peripeteia of the Good

${ }^{4}$ Eugeniusz de Henning-Michaelis, Duch $i$ technika (Odczyt wygtoszony dnia 26 czerwca $w$ Kijowie, urzadzony staraniem towarzystwa polskiej wiedzy wojskowej) (Kiev and Warsaw, 1917), 16, 18. 
Soldier Švejk of the novel by Jaroslav Hašek - the flagship of local First World War-related peculiar path. Apart from Mr Švejk, however, the war of 1914-18 is far from being as well represented in the local historiography, or public memory. Contrary to many other countries, there are almost no monuments in the present Polish territory that would commemorate the killed soldiers (save for the former German monuments and Austro-Hungarian war cemeteries in former Galicia); it might even be inferred that Poles were not concerned by the conflict, and that a 'real war' was taking place somewhere else. ${ }^{5}$

Hence, there comes the question of what, actually, made Poland, or Eastern Europe, unique in this particular respect. There is presumably a twofold (if not a more complex) explanation. First, the structural discrepancies between the societies in the western and eastern Europe should be taken into account. While the Western Front was formed, as a general rule, of urbanites and workers with a background of at least several grades of primary education, many of those joining the Eastern Front were superficially educated, or merely uneducated, peasants. Most soldiers in the West could hear commands issued in their native tongues, whereas a considerable group of those fighting for the Tsar or the Emperor had to function within the language they had a poor command of, or did not regard their own. ${ }^{6}$ Although a definite majority of war veterans living in Poland and Czechoslovakia were members of no-more-existing armies, the very strong representation of Poles (an estimated 2 million $^{7}$ to 3.2 million $^{8}$ ) as well as

${ }^{5}$ Recent historiography tries to overcome that stereotypical image. See Remembrance and Solidarity. Studies in 20 th century European history 2 (March 2014) - whole issue dedicated to the First World War and its memory predominantly in CentralEastern Europe; Jenseits des Schützengrabens. Der Erste Weltkrieg im Osten: ErfahrungWahrnehmung-Kontext, eds. Bernhard Bachinger and Wolfram Dornik (Innsbruck, 2013); Włodzimierz Borodziej and Maciej Górny, Nasza wojna, vol. 1: Imperia (Warsaw, 2014). The title of the latter book (nasza wojna means our war) devoted to the history of Eastern and South-Eastern Europe during the First World War is itself a provocation against the image of not-our-war.

${ }^{6}$ The Armeeslavisch phenomenon would probably have been impossible in the British or French army. As a side remark, the dispute over the military command language occurred in the Belgian army, where commands were issued in French while most soldiers were Flemish.

${ }^{7}$ Stefan Kieniewicz, Historia Polski 1795-1918 (Warsaw, 1987), 549.

${ }^{8}$ Eligiusz Kozłowski and Mieczysław Wrzosek, Dzieje oręża polskiego 1794-1938, (Warsaw, 1973), 348-9. 
Czechs and Slovaks (1.3-1.4 million) ${ }^{9}$ wearing the Austrian, Russian or German army uniforms would have not, by themselves, translate into a powerful post-war narrative. Many of those men did not have enough of 'cultural capital' (as we would put it today) to be able to forge their experiences into a narration that could have had a lasting bearing on the collective image(s) of the war. Moreover, the political situation - the other factor that may make the difference between the two parts of Europe - was not favourable in this respect. The countries of 'new Europe' emerged thanks to the First World War, albeit their coming to the stage is not what the war was about. The new states were built on the ruins of the former order and dissociated themselves from it, which was an inherent part of their policy - at least in the ideological sphere. Thus, the discourse unfolded around the notion of a 'revolution' or 'upheaval' of the year 1918; symbolic funerals of Austria were held, with symbols of its reign being put into the coffin ${ }^{10}$; buildings epitomising (from the standpoint of the new authorities) the bygone regimes were demolished: such was the case of St. Alexander Nevsky sobor and a dozen-or-so other Orthodox churches in Warsaw, Bismarck's towers, Prague column of Our Lady, or monuments of Emperor Joseph II. 'Restored independence' and 'foreign revolution' - i.e. the activities of Czechoslovak politicians and military formations in the Entente countries - became the dominant narrative lines after 1918 in Poland and Czechoslovakia, respectively. Stories on the war were mainly based on the history of the several dozen thousands of soldiers who, within their national formations (Polish or Czechoslovak legions), at the side of the powers' armies, struggled for their own country, as well as the history of their political leaders, owing to whose endeavours the state appeared. Feted and commemorated were soldiers of national formations and the fighting waged after 1918 by the new states, which Winston Churchill called, somewhat disparagingly, 'the wars of the pigmies': Poland, namely, had its wars for the frontiers, the risings and, in particular, the Polish-Soviet War;

${ }^{9}$ Ivan Šedivý, Češi, české země a velká válka 1914-1918 (Prague, 2001), 20. For an interesting breakdown of demographic changes in 1914-18, see the Czech Statistical Office's official website (only with respect to the Bohemian Crown lands, without Slovakia; cf. http://www.czso.cz/csu/2005edicniplan.nsf/p/4016-05 [05.05.2014]).

${ }^{10}$ See Andrzej Zięba and Wojciech Rojek, Stan świadomości narodowej Polaków w przededniu niepodlegtości (Cracow, 2009), ill. 223. 
Czechoslovakia, at a smaller scale, fought against the Hungarians (of the Hungarian Soviet Republic and were engaged against the Poles in Cieszyn Silesia. The newly-emerged states had no real interest in identifying themselves, in any way whatsoever, with the parties to the 1914-18 conflict; ideological dissention against them could basically be profitable since the no-more-existent opponents: the Habsburgs, the imperial Reich or the tsarist Russia, could be burdened with the wartime destruction, wounds, and resentments.

In-depth analysis of both arguments indicates that the social factor was of lesser relevance than the political factor. The former argument weakens when referred to the facts and specific details of the Polish, or Czechoslovak, case: whilst the Russian or Austro-Hungarian army consisted of peasants to much a larger degree than the French or English army, the Czech lands were urbanised and industrialised to no lesser an extent than the urban regions of France or Italy. Again, a definite majority of Poles in the German army (their overwhelming majority having graduated from a school) fought with the Western, rather than Eastern, Front. ${ }^{11}$ The differences between the "national and urbanised' army of Western Europe and the 'imperial and peasant' army of the East are undisputed; yet, the peculiarity of the Polish and the Czech case is such that they elude such simple dichotomic divisions. This issue is worthy of separate analysis. On a tentative basis, it may be assumed that in terms of social structure Polish and Czechoslovak First World War soldiers formed part of the patchy, or heterogeneous landscape of European armies that embraced members of all the social classes.

The political argument gains, in turn, in relevance under the assumption that veterans form a group whose existence is based not solely on the individual experience of fighting and individual memory of it, but primarily on the relationship with an organised community of comrades-in-arms and with the state, as an institution which is to add meaning to such experience. The state ought to confirm the importance of veterans, emphasise their merits, and reward them in both symbolical and material terms. As far as Poland and Czechoslovakia are concerned, the situation after 1918 was such that the war-waging states had disappeared and in lieu of them there appeared

11 See Ryszard Kaczmarek, Polacy $w$ armii Kajzera na frontach I wojny światowej (Cracow, 2014), esp. 315-90. 
countries not much willing to have to do with the war - but amongst their citizens was a multitude of former soldiers of alien armies. Both countries had to somehow determine their relationship with their respective veteran communities (and, vice versa).

This rather paradoxical situation was, in fact, constitutive to the distinctive character of the Polish and Czechoslovak case. Many other countries, after the post-war shifts of borders, were home to those who not long before then fought against these countries. The Alsatians in France, the Hungarian soldiers from Transylvania in Romania, the Austrian soldiers from Tirol in north-eastern Italy, and more than a half of the citizens of the Kingdom of the Serbians, Croatians and Slovenes, who until 1918 had been subjects of the Habsburgs. In each of these cases, the ex-combatant question was among the many elements of a wider issue - namely, integration of the newly-annexed territories with the rest of the country (unification of the legal system, economic, social and symbolical integration, etc.). In none of them was the country being party to the war completely replaced by a new state entity that would determine its stance with respect to the war somewhat on an ex-post basis.

Table 1. Potential categories of veteran-state relations in post-war Europe.

\begin{tabular}{lll}
\hline \multicolumn{1}{c}{ Veterans } & \multicolumn{1}{c}{ 'Old' country } & \multicolumn{1}{c}{ 'New' country } \\
\hline \multirow{2}{*}{ 'Our men' } & $\begin{array}{l}\text { United Kingdom, Germany, } \\
\text { Hungary, Bulgaria }\end{array}$ & $\begin{array}{l}\text { Ireland(?), Finland, } \\
\text { Baltic countries(?) }\end{array}$ \\
\hline \multirow{2}{*}{ 'Our' vs. 'alien' men } & $\begin{array}{l}\text { France, Italy, Romania, } \\
\text { Belgium }\end{array}$ & $\begin{array}{l}\text { Kingdom of SHS/ } \\
\text { Yugoslavia }\end{array}$ \\
\hline \multirow{2}{*}{ 'Not our men' } & & $\begin{array}{l}\text { Russia/USSR, Poland, } \\
\text { Czechoslovakia }\end{array}$ \\
\hline
\end{tabular}

First developed before the war ended, the relationship between former-order countries and former soldiers was for the most part based, mainly in Germany and Austria, on aid-providing and commemorative

${ }^{12}$ Situation in all states in that position is disputable. For example in Ireland it has evolved from public distancing from the First World War as British and imperial war in the Free Irish State in 1920s and 1930s to its gradual acceptance and incorporation into public remembrance since 1940s. See Mandy Tonwnsley, "'Neither for King, nor Empire": Irish Rememberance of the Great War in the 1920s' Remembrance and Solidarity. Studies in 20 th century European history 2 (March 2014), 147-72. 
actions, including interim pensions and collections, the idea of lodges for the disabled, decoration and (particularly, Austrian) cemetery policy. This relationship was broken in the lands of what was to become Poland and Czechoslovakia in the autumn of 1918, whereas the newly-emerging states had to create, anew and in their own way, the relations and relationships with the ex-combatant communities. It is from this perspective that the situation of veterans was unique in both countries, for the new states were (or were not) taking over the obligations and undertook, as it was described by Czechoslovak Social Care Minister Lev Winter as "healing the wounds inflicted by the war", to solve the veteran question.

Furthermore, untypical to other societies was the dualism of the former-combatant milieu: along with a host of former soldiers of the former armies, the much lesser-in-number Legionnaires and 'independence fighters' appeared ${ }^{13}$ : the name described members of the formations that were set up at various moments of the war and functioned as affiliated to the respective powers' armies, while retaining their 'national' quality. As far as Poland is concerned, this was the case of (mainly) Polish Legions and the formations derived from them, three Polish Corps in the East, formed after the 1917 February Revolution of a group of Polish soldiers in the Russian army, and the Blue Army (Btękitna Armia) set up in France. There also were several lesser formations, such as the Puławy Legion (Legion Puławski) or minor troops in Italy or Finland. As for Czechoslovakia, there were the Czechoslovak Legions: French, Italian and Russian (the latter being the largest), and some smaller formations preceding them. In both cases, the aggregate number of member soldiers was not more than 100,000 - this being incomparably less than the veterans of the 'regular' armies. Although a significant group of 'independence fighters' or legionnaires joined their troops after serving with the Austrian, Russian or German army, usually via captivity or, as with some Polish Legionnaires after the July 1917 Oath crisis were dressed into Austrian uniforms after their service with the Legions, the difference between a 'legionarz' or 'legun' (colloq., Legionnaire) and a 'rakuszak'

13 'Independence fighters' (resp., 'independence adherents' - Polish, niepodlegtościowiecs) was a name half-officially used in the Second Republic of Poland to denote the members of military, insurgent and conspiratorial formations from the period 1905-21. 
('Austrian') was decisive for the main break line as far as the stateveterans relations are concerned. This division has only partly been erased by the experience of formation of the Polish and the Czechoslovak army, which - in both cases - consisted in merging the military structures and formations remaining of the predecessors with the 'national' troops. However, in the early 1920s, after the armed conflicts came to an end, the demobilisation was completed and a system offering support to former soldiers has developed, these differences became of relevance again. Throughout the two decades between the World Wars, there was a certain duality in the policies pursued by the Polish and Czechoslovak states with respect to their veterans: the Legionnaires and the 'independence fighters' were treated in a special way, even if this was not quite reflected in the legal system or in the official discourse.

III

WHO IS A VETERAN?

Apart from the damages it brought about, the war of 1914-8 caused more than every third soldier in Europe was affected, in one way or another: mutilated, crippled, or wounded; this extended to twentyplus million males. Added to these war victims was a not much lesser number of widowed and orphaned relatives of those killed. What it meant for the post-war state structures was a challenge of creating a social and medical system that could have somehow cope with this universal social problem of unprecedented magnitude; suffice it to remark that the French Disabled Act adopted in 1919 came in lieu of a, say, peer deed dating back to 1831 .

Such rescaling of the problem implied a major semantic change. In the late nineteenth century and several years thereafter, for most countries war was a remote reminiscence of the years 1866 and 1870-1; a 'veteran' was associated, at most, with an oldish fancier of pipe and beer, a member of some Kriegerverein who would meet his mates once in a month to feast and revel, and join the colour party on a national holiday, twice or thrice a year (the ruler's holiday, a victory day, or the like), marching to the church and to a local monument. Encyclopaedias and dictionaries before 1914 described 'veteran' as, primarily, “old and experienced Roman soldier, 
particularly, in the late years of the Republic". ${ }^{14}$ After the Great War, the word and notion returned from Ancient Rome to the present and began referring ever since, simply, to former and quite experienced soldier; organisations of such veteran soldiers, an encyclopaedic definition explained, "care about strengthening the spirit and preserving the military tradition". ${ }^{15}$ This was a direct reference to the post-war reality. Most the Great War veterans (sometimes named wojaks in Poland - voják in Czech meaning, simply, 'soldier'), once back from the war front, were still young men, aged usually below thirty, some of them having been through severe traumas; now, their personal sense of merit for their homeland at times faced the hard fact that there was no decent place for them when back home. The aura of pessimism prevalent in the interwar years, and of disillusionment as to human nature, was contagious also to those former soldiers and provoked a variety of attitudes: passiveness and retreat (many of the soldiers never joined a veteran association); pacifism and all shades of political involvement; or, radicalism - in a fascist or communist fashion. A good illustration is Germany, where a few powerful rightist organisations (old- and new-style ones, such as, respectively, Kyffhäuser or Stahlhelm) functioned until 1933, along with a socialdemocratic, Catholic, Jewish, and communist organisation. Mass war-veteran organisations all over Europe became ever since one of the essential drivers of political life and of mass politics of the "new model'. Former soldiers marched or paraded in their uniforms along city streets, protested or supported, chanted slogans for or against, had their MPs elected, and penmen siding with them. They formed the main engine and propelling force behind the pacifistic currents (as in France), joined and supported paramilitary storming parties or armed bands (just to mention the Italian fascists). The radical atmosphere of the interwar Europe and the conflicts it produced are explainable, among other things, by the stigma impressed by Great War on the ex-combatant generation.

${ }^{14}$ Ottův naučný slovník. Illustrovaná Encyklopaedie obecných vědomostí, vol. 26 (Prague, 1907), 623.

${ }^{15}$ Masarykưv Slovník Naučný. Lidová Encyklopedie všeobecných vědomostí, vol. 7 (Prague, 1933), 633. 


\section{IV \\ WHO IS A POLISH AND CZECHOSLOVAK VETERAN?}

In this respect, it could have seemed that Poland and Czechoslovakia functioned, as it were, in a somewhat different space. Proactive pacifism, especially in Poland, was characteristic, above all, of intellectuals, many of whom - such as the once-pacifist Józef Wittlin ${ }^{16}$ would quit this attitude with time, finding that

[pacifism] is presently [in mid-1930s] merely a trend yielding sentimental results, and there is no positive force it might offer. In case a war breaks out, our pacifists will go to the front. We find pacifistic literature moving, but it has not affected our lives. ${ }^{17}$

Whenever pacifist tones appeared in the discourse of war veterans (especially, disabled ex-combatants), the reservation would immediately be voiced that the home country's independence and borders should always be fought for, if such need ever arises. A similar situation in this respect appeared in Czechoslovakia. Karel Čapek, who personified the democratic and liberal ideals of his country, from 1936 onwards fought severely for pacifism against Jaroslav Durych, a Catholic writer who considered his adversary's antiwar stance as cowardice and 'morality of the C category' ${ }^{18}$ However, in September 1938 in face of the German aggression of 1st October 1938, both authors signed, in concert, the letter of the Association of Czechoslovak Writers to the international public opinion, which declared the signatories' will to "spare no effort in our fight for liberty of our country". ${ }^{19}$

${ }^{16}$ Marian Stępień, 'Inwalida pierwszej wojny światowej', in idem, Wśród emigrantów (Cracow, 2007) 165-77.

${ }^{17}$ Józef Wittlin, Pisma pośmiertne i inne eseje, ed. Jan Zieliński (Warsaw, 1991), 145.

${ }^{18}$ Category 'C' stood for 'unfit for military service' As Durych puts it: "Není ještě největším hříchem proti českému jménu Haškův román o Švejkovi. Je ještě něco horšího a to je morálka "C», morálka nezpůsobilých, kterou jest náš lid přeplněn. Je to taková morálka způsobná, na první pohled lidová a lidumilná a uctivá a laskavá ..., ale pozor! ... Čtu tedy Karla Čapka nikoliv jako spisovatel, nýbrž jako vojenský lékař. Poznávám jeho $\mathrm{C}$ a bojím se. Bojím se všeho, co je C. Umím si představit, co by se stalo, kdyby se morálka $\mathrm{C}$ zalíbila povětší části národa. Před tím nás zachovej Bůh." Quoted after Jaroslav Durych, Publicista, ed. Zuzana Fialová (Prague, 2001), 297-8.

${ }^{19}$ Katya Kocourek, Čechoslovakista Rudolf Medek. Politický životopis (Prague, 2011), 190-1. 
On the other hand, the fascist movements that were developing there were rather weak and had a limited room for action and influential power on the society. The Národní obec fašistická, established in Czechoslovakia in 1926 - albeit run by the legendary Legion general Radola Gajda, one of the commanders of the Czechoslovak troops in Russia, nicknamed 'Siberian Lion', known for his courage and no good political sense - never won support above 2 per cent (as in the 1935 parliamentary election) and mostly functioned on the margins of political and legionary life. ${ }^{20}$ In Poland, on the other hand, fascist projects emerged out of the national movement and were fathered by 'civilians' such as Roman Dmowski, with his Camp of Great Poland; otherwise - the case of the National Radical Camp - they developed thanks to members of the 'infantile age groups', as Sebastian Haffner named his age-peers ${ }^{21}$, which was meant to refer to those for whom the First World War was a childhood-years fascination, rather than personal warfront experience. For the Polish fascists, the first war they personally encountered was, if anything, the Polish-Bolshevik War of 1920.

With so modest a participation of former soldiers in the ranks of fascist and pacifist organisations, where was the rest of them? In respect of former soldiers of the partitioning countries' armies (i.e. Austria, Prussia and Russia), the answer is apparently rather simple: most of those people were inactive, and they did not form a single veteran milieu. The wartime service and the experience and skills gained through it helped some of them pursue social, or even political, activity in their local environments, when back home. So, we can find them in rural cooperatives, communal councils, societies and association, or even in the Military Reserve Association. There

${ }^{20}$ It is worth mentioning that the role of Gajda (his real name being Rudolf Geidl) and his presumed plan for upheaval in June 1926 has been subject to polemic till our day: it is not certain whether the coup was real, or was perhaps the Hrad's illusion, which turned into self-fulfilling prophecy. It was only the accusation of leading a fascist upheaval that turned Gajda into a genuine fascist. See Antonín Klimek and Petr Hofman, Generál Radola Gajda, vitěz, který prohrál (Prague, 1995).

21 "It is there that the roots [of Nazism] are struck: not in the 'warfront experience' but in the wartime experience of German schoolboys. ... The real Nazi generation is formed ... of those born within the decade 1900-10, who experienced the war as a great spectacle, unharmed by the reality." Sebastian Haffner, Geschichte eines Deutschen. Die Erinnerungen 1914-33 (Stuttgart, 2000). 
were many such who contained their wartime past within the family and neighbour circle, though; if they experienced suffering due to the war, they usually did it in secrecy. ${ }^{22}$ If they wrote and published memoirs, they mostly exculpated themselves from their service with the armies of the once-partitioner countries, emphasising their individual patriotic incentives. The trend of 'deserter and malingerer' reminiscences developed especially in Czechoslovakia ${ }^{23}$, where the authors proposed the attitudes of passive or active resistance of Czech soldiers against the 'Austrian hydra's' army served as a model worthy of following. In Poland, particularly after 1926, most of the authors of published memoirs (such publications being rather scarce, compared to those produced by former Legionnaires) referred their military service to their belief in the 'Polish cause', arguing that they essentially would have clearly been willing to join the Legions. Also popular culture solidified this concept and the related images. Dodek na froncie, a comedy film from 1936, features as the main character, starred by the famous comedian Adolf Dymsza, an Austrian soldier named Wędzonka ('Bacon') who does not take the war too seriously, but when he strives to take a nap when a shelling is on, he asks his officer when he could finally expect to be removed to "our Army - the Legions". ${ }^{24}$

Among the former soldiers of partitioner armies, the disabled were the most active group. For them, banding together, forming unions and pursuing activities were one of the ways to ensure independence in life. Disabled veteran associations solicited state licences for their members to run tobacco-shops, small-scale production businesses, and the like. In this respect, there was no major difference between the situation of Poland, Czechoslovakia, Germany, or France: invalids were one of the interest groups which, with a better or worse result, endeavoured to meet their targets. The specificity about Poland was, however, that victims of the war were categorised by the uniform

${ }^{22}$ As Katarzyna Sierakowska observes, "the unwilling avowal of sufferings related to the war among soldiers ensued, on the other hand, from the patriotic duty, as they realised it, and on the other, from the binding pattern of masculinity." Eadem, "Niech się nasi bracia, ojcowie i matki dowiedzą ..., jakich se to wychowali bohaterów.” Cierpienie w relacjach żołnierzy Polaków 1914-1918', in Zapisy cierpienia, ed. Katarzyna Stańczak-Wiślicz (Wroclaw, 2011), 272.

${ }^{23}$ Domov za války. Svědectví účastníků, ed. Alois Žipek, 4 vols. (Prague, 1929-30).

${ }^{24}$ Dodek na froncie, directed by Michał Waszyński, 1936; http://youtube/_ IHY9tg75pI?list=PLBBECE92574DAC2D6 [15.12.2014]. 
they actually wore: hence, the classification into 'Polish' invalids and 'disabled Poles'. As Bolesław Kikiewicz, a physician actively pursuing the affairs of the disabled in the interwar years, tersely put it in 1919: "The disabled of the Polish Army deserve gratefulness; those of the alien armies deserve just compassion." 25

The war veterans who resolved to join any of the official veteran organisations (whose number was, as was said, relatively low) became, in one way or another, integrated in the political order established in their country. In 1928, a Federation of Homeland Defenders' Associations (Federacja Polskich Związków Obrońców Ojczyzny, FPZOO) was set up in Poland as a roof organisation for all the veteran organisations supporting the Sanacja regime. In practice, with use of not thoroughly legal or democratic but efficacious measures, the Federation managed, by the early 1930s, to subjugate a huge majority of former soldiers' organisations: starting with the Legionnaires and Polish Military Organisation (POW) members (who did not quite need being subdued), through Silesian Uprising soldiers, the handicapped and reservists, and ending with large groups of former soldiers of Blue Army, or of the three Polish Corps in the East, who before then were associated with the Polish right-wing milieus. As was the case with the Opposition parties, veteran organisations that opposed the Federation - such as Związek Hallerczyków (union of former subordinates of General Józef Haller) or Stowarzyszenie Dowborczyków (association of former members of General Józef Dowbor-Muśnicki's 1st Polish Corps in Russia; the organisation used the catchword 'Glory to the Homeland!') could function legally, albeit their reach and interaction strength were restricted by the authorities and discreetly controlled: the voivodeship administrations received on a regular basis, from the late 1920s on, notifications concerning the activities of former Haller men and what Mr Haller was doing, and where. In Czechoslovakia, the major associations were formed of local legionnaires. While, since 1921, a strong and dominant organisation named Czechoslovak Legions Community (Československá obec legionářská, ČsOL) existed, there were other former military-men's organisations functioning: the rightist Nezávisla jednota československých legionář̀u (NJČsL), a Catholic Legionnaires' association (active mostly in Moravia), and more. In spite of clearly visible differences and disputes between them, virtually

${ }^{25}$ Bolesław Kikiewicz, 'Inwalidzi “polscy” a inwalidzi Polacy’, Inwalida, 8 (1919), 1. 
none of these organisations did transgressed the ideological or notional spectrum of the Czechoslovak democratic political scene. And, all of them, each in its peculiar way, emphasised loyalty toward the state and its President-Liberator. Quite obviously, the ČsOL excelled in this area, organising ostentatious conventions every few years in Prague to express their support for the authorities. Other organisations fully identified themselves with the idea of 'Czechoslovakism' as well.

\section{$\mathrm{V}$ \\ THE DISABLED: SHARED PROBLEMS, PARALLEL SOLUTIONS}

As was the case with all the other countries whose population was involved in the war, Poland and Czechoslovakia had to face the effects of the First World War, primarily in their social dimension. Therefore, parliamentary acts regarding war disabled persons were issued to regulate the employment, pensions, and allowances for handicapped veterans. The practice of medical assessment of health impairment in percentage terms, elaborated in the late period of the war, was quite easily adopted in Europe: thus, veterans appeared before boards composed of physicians and officials that granted them a health status - primarily, in terms of ability to work. Usually, the threshold of 15 per cent impairment was the low limit as from which eligibility for a pension, be it symbolic, was identified. The disabled laws extended also to preferences in employing the disabled, at least with public (state or local-government) offices or enterprises. Other privileges included sanatoria (though not satisfactory in terms needs versus availability), workplaces for the handicapped, and the like. The issue of persons injured by the war was thus contained within the medical and social discourse. 'Former soldier' was regarded in terms of being a war victim, a medical case, and a social problem. Such perspective on harm, or wrong, implied a specific egalitarianism in relation to the victims: rather than depending on the period served or military rank, their benefits were primarily based on health impairment rate. ${ }^{26}$

${ }^{26}$ It should also be pointed out that, for instance, in Romania the right to disability emolument extended to all the disabled ex-soldiers, regardless of the army they had been with. Apart from the health condition, the amount claimable depended on the military-service rank. See 'Zaopatrzenie inwalidów i pozostałych', Inwalida, 24-25 (1928), 2. 
This is also visible in the thousands of commemorative plaques featuring names of the killed (there being not many such plaques in Poland): these names are, in vast majority, ordered not by military rank (officers - non-commissioned officers - soldiers) but by keys, such as chronological (those killed in 1914, 1915, ...), geographical (natives of locality X, Y, ...), or, simply, sequenced in alphabetic order.

In Poland and in Czechoslovakia alike, the disabled laws mostly reproduced a majority of the solutions applied in France and elsewhere. ${ }^{27}$ It was essential that these laws were meant, not without dispute, to extend to all the harmed soldiers, regardless of the army they had served with. Within such an 'injury perspective', all the soldiers were supposed to be equal, even though they might have only deserved compassion. While the systems offering social support to former soldiers showed many similarities, it seems that Czechoslovakia managed to make up a more efficient system which was somehow friendlier to its 'consumers'. For the Prague elite, construction of a social justice state was, after all, a major reason to be proud. Although in Tomáš G. Masaryk's country the minimal benefit was vested in veterans whose inability to perform gainful work was 20 per cent minimum, the number of those receiving disability (or, widow's pensions) was similar to that in Poland, if not, at times, bigger. As of 1927, Czechoslovakia recorded 112,000 disabled persons claiming a pension, along with 350,000 members of their families. ${ }^{28}$ In parallel, Poland had 100,000 and 180,000 in the respective categories. Any handicapped individual willing to receive state aid in the Second Republic had to get registered on his own. Hence, one may refer to a 'grey zone' of the invalids who remained not covered by the state register - which is particularly true for eastern provinces and rural areas. Still in the mid-thirties, governmental decrees referred to registered and unregistered invalids, the latter missing in any records and not subjected to medical examination. The deadline for completion of the registration of war-disabled persons was postponed in both countries several times. Medical boards did not win much trust

27 The Czechoslovak law: 'Zákon ze dne 20. února 1920 o požitcích válečných poškozenců', in Sbirka, 142 (1920); the Polish peer law: 'Act of $18^{\text {th }}$ March 1921 on protection of war-disabled persons and their families and on benefits vested in families of the fallen and dead whose death is in a casual relationship', in Journal of Laws, 32/195 (1921); another such deed was issued in 1932.

${ }^{28}$ Deset let Československé republiky, vol. 3 (Prague, 1928), 132. 
or reliability in Poland; as a joke from a calendar for the disabled had it: "Any disability ... shall be radically removed by so-called Superrevisory Military-and-Medical Boards for the Handicapped."29

The assumption that the handicapped are equal in face of detriment was undermined in Poland during the Great Depression. The authorities, in search of saving options and by cutting public expenditure, resolved in 1932 to increase the minimum threshold of disability entitling to pension benefits from 15 per cent to 25 per cent. However, this only concerned soldiers of former partitioning powers' armies, while 'independence fighters' and former Polish Army soldiers still claimed pensions when disabled at 15 per cent or above. This is how the concept first expressed in 1919 by Kikiewicz was put into practice. For the record, it should be added that in the late 1930s, with improving economy, the restrictions for the handicapped that had served in the alien armies were abolished.

\section{VI \\ VICTORS OF NOT-THEIR-WAR}

It was not the disabled (in spite of their considerable numerical force) that formed a dominant ex-combatant milieu in the re-established Poland or in Czechoslovakia. Promoted to a dominant position were those who considered themselves the winners of the war - as they were feted in their countries as such. These former legionnaires, Polish and Czechoslovak ones, perceived the war in rather ambivalent terms: they rejected the ideas in the name of which the war had been waged but identified themselves with its outcome. This was meant, from a post-war perspective, to put the Polish soldiers first: those who fought for Poland, although the cause was not theirs. This is visible, for example, in one of the many Polish critical reviews of Erich Maria Remarque's All Quiet on the Western Front - the book that was extremely popular in the interwar period, also in Poland (the review was published in Federacja, the press organ of the FPZOO):

No Polish poet-of-the-book would be capable of writing a book as if he were a Remarque. No Polish story of the fighting in the years 1914-20 sounds like the Remarque book. ... For, that war was not ours. ... We have never

${ }^{29}$ Inwalida. Kalendarz 1924, nakładem Zarządu Głównego Związku Inwalidów Wojennych RP (Warsaw, [1923], 60. 
believed in the War - what we believed in was Freedom. ... And it was at that same time that we marched forward, infatuated with the bridge Polish sky. This is exactly why Polish soldiers could perish with a smile on their faces, shouting boldly, 'Long live Poland!' And this is why German soldiers were dying morosely and in silence. None of them could shout, 'Long live Germany!': none fought for their Germany's freedom. ${ }^{30}$

Such an attitude, expressed over and over in the veteran press, propagandist addresses, and elsewhere, in a multitude of ways, constituted the foundation upon which the entire veteran explanation of the past, and of the present was built. Victory in a war one would not identify himself with was well received within the ideological context of the restored state: while dissenting from a war disaster, its positive results - so perceived from the Polish standpoint - were considered 'our own'. The suffering, dismal recollections, complaining about war-inflicted wounds, and so on, befitted disabled individuals; 'Polish soldiers' who saw themselves as victors in this war, could, at most, 'perish with a smile on their faces'. 31

Yet, the relation between the sense of victory or loss and selfidentification with the war could in different countries or groups appear in the form of a combination. Countries such as France, United Kingdom, Belgium or Romania had very good reasons to consider themselves winners of their war. Italy could be included in this group; however, as some territorial claims written down in the London treaty of April 1915 has not been fulfilled, Italy considered its participation in the war to have been a Pyrrhic victory. Germans, Bulgarians, Turks and Hungarians had, otherwise, to digest their awareness of having lost in this war, a war they identified themselves with - even if they could accuse for the defeat suffered some sinister forces inside or outside their own country: be it communists, Jews, Slavs, Romanians

30 Adam F. Augustynowicz, ‘Żołnierz polski i żołnierz niemiecki w dobie ostatniej wojny', Federacja, 5-6 (1929), 36.

${ }^{31}$ It is worth adding that such 'state-made' clarification of the role of Polish war veterans could remain unaccepted by some veterans, especially those from the former partitioning armies. This is pretty well attested by the fact that Remarque's novels were distributed across Poland, selling thousands of copies - whilst Federacja, which published the quoted review, was closed down in 1931 - a mere three years from the date the first issue was published - owing to poor response among readers. See Marek Jabłonowski, Sen o potędze. Z dziejów ruchu bytych wojskowych w II Rzeczypospolitej (1919-1939) (Olsztyn, 1998), 300. 
(in the case of Bulgaria), and so forth. Those who did not take the war as theirs could well consider themselves losers as well: such was the case with the Ukrainians, whose attempts to build a sovereign statehood structure on the ruins of the old order ended up in failure. There existed societies which did not identify themselves openly with the war as such but considered themselves the winners: apart from Poland and Czechoslovakia, let us just mention the Baltic countries or Finland. Finally, there were countries such as Yugoslavia where two or three such attitudes blended together.

This complicacy of the relations between approaching the War as one's own or not one's own and the sense of doubt or debacle was even reflected in the 'inter-alliance ex-combatant federation' - Fédération interalliée des Anciens combattants, which comprised organisations from the world over. In terms of the assumptions - as reflected in the name - the member veterans were to come from Entente countries only, but in fact the Federation was joined by veteran organisations from countries officially regarded as victorious. Apart from France, the U.S., Britain, Portugal, or Belgium, there was Yugoslavia, Czechoslovakia, and Poland: as is known, in the latter, former Polish Legions' members were in the lead - the Legions, in fact, being the formation that fought during the war against the Entente.

In this respect, in spite of a sense of uniqueness emerging and reinforced amongst Polish veterans, the Polish case was not unique at all. The topos of internecine struggle, as expressed in Edward Słoński's wartime poem $\mathrm{Ta}$ co nie zginęta ("There's two inimical retrenchments, // Me and you standing there"), was quite pervasive also in the case of Yugoslavia, Romania, or, at a smaller scale, Czechoslovakia. Identification with the war's outcome, while the war as such was rejected, was typical of most of the 'New Europe' countries, having emerged, after all, on the ruins of the order the war had demolished.

\section{VII \\ SUMMARY: POLISH WAR VETERANS FOLLOWING A SEPARATE PATH?}

In the conclusion of his book about the position of the First World War in European cultural history, Jay M. Winter rather unexpectedly refers, at some point, to our leading idea of Sonderweg, the separate path. He namely finds it, once again, that the conflict of 
1914-18 killed millions of people, and, "all too often victory had a taste of ashes":

Recalling this aspect of the war also helps to cast further doubt on the outmoded idea that Germany went through a special path, a Sonderweg, in the nineteenth and twentieth century. As we have now seen, all major combatants went through a 'special' path, the path of a collective slaughter. ${ }^{32}$

It would be difficult to oppose this argument: there is no point debating the specificity of wartime sufferings and problems of former soldiers. When it comes to sheer war experience or human tragedy, there are no separate paths for countries or nations: pain, yearning, hatred, fear, courage - are virtually all the same. However, when looking at the locations of veteran communities in the post-war realities of individual countries, Poland and Czechoslovakia have an evident specificity to them. Obviously, as is the case with the other applications of the 'separate path' category, it is key to clearly determine the elements we expect to consider peculiar, specific, as well as the criteria used to compare them against the (possibly) peer phenomena. The developmental specificity of a historical phenomenon can only be described in relative terms.

The functioning of the First World War veterans in Poland (and in Czechoslovakia) was dissimilar to that in other West European countries (such as France, UK, Germany, or Italy). It was moreover different from how the ex-soldiers functioned in some other 'New Europe' countries, mostly in that it was based on the split into a milieu of 'Polish soldiers' (Legionnaires, Gen. Haller army members, etc.) and 'Poles the soldiers' of what was the partitioning countries' armies. Such categorisation implied a privileged position of the former group, which was expressed symbolically, politically and, at times, also in economic favours - such as eased job opportunities. Veterans representing the national formations were easily integrating with the state ideologies, often becoming their inseparable element - one example being the Czech Legionnaires keeping watch in front of all residences of the Republic's President. In parallel, both Poland and Czechoslovakia took over a series of Western institutional and legal solutions and attitudes as far as various ex-combatant issues were

32 Jay M. Winter, Sites of Memory, Sites of Mourning: The Great War in European Cultural History (Cambridge, 2010 ${ }^{11}$ ), 227. 
concerned. The disabled social care system, the Unknown Soldier Tomb and other ways and methods of commemorating, inclusion of war veterans in state ceremonies and rituals - all resulted from the transfer of Western models to the East. Owing to the diverse political contexts, the models or patterns did not work in the same way everywhere. While in the West they would potentially have been applicable to each one of the millions of Great War ex-soldiers, elsewhere their significance would be limited to the 'independence fighter' milieus. In its Warsaw version, the Tomb of Unknown Soldier, originally devised as commemorating all the soldiers killed during the First World War, primarily extended to those fallen in Polish formations' struggles for independent Poland (the Tomb's plaques specified the names of battles and military operations of Polish Legions and Polish Army from 1914-21). Although the disabled pensions were commonly measured in terms of health impairment, it appeared in moments of economic shrinkage that for any support at all to be allocable to them, ordinary soldiers had to be found harmed severer than 'independence fighters'. If there was a Polish (or, as a broader concept, Central-European) specificity of the situation of the First World War veterans, all it was about was the fact that the political context of the new states favoured a peculiar transposition: the minority formations of veterans associated with the national formations came in lieu of what would elsewhere have been mass associations of veterans of the country's own armies. As for Poland and Czechoslovakia, then, one can essentially refer - somewhat metaphorically - to two diverse generations of ex-combatants, forming a demographic unity. One of these generations consisted of those (rather scarce in number, but enjoying their privileges) whom Starzyński once aptly described as 'merited for the country', the circumstance which entitled them to deciding the country's fate; these people eventually made their own experience part of the state-supported vision of the world. The second mentioned generation consisted of a majority of regular soldiers for whom the War had become part of their individual biographies but who never had an opportunity to build a community of memory or interest shared with the others.

trans. Tristan Korecki 


\section{BIBLIOGRAPHY}

Borodziej Włodzimierz and Górny Maciej, Nasza wojna, i: Imperia (Warsaw, 2014). Eichenberg Julia, Kämpfen für Frieden und Fürsorge. Politische Veteranen des Ersten Weltkriegs und ihre internationalem Kontakte, 1918-1939 (Munich, 2011).

Henschel Christhard, “"Jeszcze nas straszą żywe upiory bez nosów...” Kilka uwag o miejscu kombatantów i inwalidów wojennych w społeczeństwie polskim w latach 1918-1939', in Mateusz Rodak (ed.), Margines spoteczny II Rzeczypospolitej (Metamorfozy społeczne, vi, Warsaw 2013), 86-103.

Jabłonowski Marek, Sen o potędze. Z dziejów ruchu bytych wojskowych w II Rzeczypospolitej (1919-1939) (Olsztyn, 1998).

Mierzwa Janusz, Kombatancki Kraków 1918-1939 (Cracow, 2002).

Prost Antoine, In the Wake of War. 'Les Anciens Combattants' and French Society 1914-1939 (The Legacy of the Great War), tran. Helen McPhail (Oxford, 1992).

Šedivý Ivan, 'Zur Loyalität der Legionäre in der Ersten Tschechoslowakischen Republik', in Loylitäten in der Tschechoslowakischen Republik 1918-1938. Politische, nationale und kulturelle Zugehörigkeiten, Martin Schulze Wessel (ed.) (Munich, 2004).

Stegmann Natali, Kriegsdeutungen - Staatsgründungen - Sozialpolitik: Der Helden- und Opferdiskurs in der Tschechoslowakei 1918-1948 (Munich, 2010).

Winter Jay, Sites of memory. Sites of Mourning: the Great War in European Cultural History (Cambridge, 1995). 